\title{
KEELEKASUTUSE ALUSPÕHIMÕTTED EESTI VABARIIGI PÕHISEADUSES JA NENDE RAKENDAMINE
}

\author{
Ilmar Tomusk \\ Keeleinspektsioon
}

\begin{abstract}
Ülevaade. Artiklis vaadeldakse keelekasutust sätestavaid norme Eesti Vabariigi põhiseaduses, et välja selgitada, mil määral tagavad need eesti keele kasutamise kõigis olulisemates eluvaldkondades; kas need on piisavad eesti keele arendamiseks ja kaitsmiseks ning isikute keeleõiguste tagamiseks.

Põhiseaduse keelesätete analüüs näitab, et keelekasutuse põhimõtted on põhiseaduses kirjas piisava selguse ning üksikasjalikkusega, võimaldades täita põhiseaduse preambulis seatud eesmärki tagada eesti rahvuse, keele ja kultuuri säilimine läbi aegade. Eesti keele kasutamine on tagatud põhiseaduslike institutsioonide tegevuses ning enamikus eluvaldkondades. Mõnes valdkonnas (kohalike omavalitsuste asjaajamine, haridus, meditsiin) jätab aga põhiseadusega antud eesti keele kasutamise võimaluste rakendamine soovida.

Neid puudujääke on üritatud korvata riikliku keelejärelevalvega, kuid keelepoliitika heitlikkust, õigusaktides esinevaid puudujääke ja keeleoskuse probleemidest möödavaatamist ei ole võimalik järelevalvemeetmetega parandada. Põhiseadust aluseks võttes tuleks parandada seadusi ja rakendusakte.
\end{abstract}

Märksõnad: Põhiseadus, riigikeel, asjaajamiskeel, kohalik omavalitsus, haridus, tervishoid, riiklik keelejärelevalve

DOI: https://doi.org/10.12697/jeful.2017.8.1.16

\section{Sissejuhatus}

Keelepoliitika (ingl language planning) all peetakse silmas keelte kasutamist reguleeriva ametliku poliitika väljatöötamist ja rakendamist (Crystal 1992). Iseseisvumise taastamise järel on Eesti keelepoliitika peamine ülesanne olnud eesti keele funktsioonide taastamine riigikeelena. Ennekõike on see tähendanud vabanemist Nõukogude okupatsiooni tagajärgedest, mille tõttu madaldus olulisel määral eesti keele staatus ühiskonnas ning ahenes selle kasutusala (G. Hogan-Brun et al. 2009). 
Kuigi juba 1989. aasta 18. jaanuaril ENSV Ülemnõukogus vastu võetud ENSV keeleseadus sätestas, et Eesti NSV riigikeel on eesti keel ning Eestimaal, eestlaste põlisel asualal on eesti keel riigi erilise tähelepanu ja kaitse all, andis seadus eristaatuse ka vene keelele. Kolm ja pool aastat hiljem rahvahääletusel heaks kiidetud põhiseaduses enam vene keelt mainitud ei ole, mis aga ei tähenda kaugeltki seda, et probleemid selleks ajaks lahenenud oleks olnud.

Eesti Vabariigi põhiseaduse (Põhiseadus 2012) preambuli kohaselt on Eesti riigi ülesanne tagada eesti rahvuse, keele ja kultuuri säilimine läbi aegade. ${ }^{1}$ Põhiseaduse $\S 6$ sätestab, et Eesti Vabariigi riigikeel on eesti keel, $\S 37$ kohaselt on igaühel õigus saada eestikeelset õpetust, $\S 51$ kohaselt on igaühel õigus suhelda eesti keeles riigiasutuste ja kohalike omavalitsustega, $\S 52$ sätestab, et riigiasutuste ja kohalike omavalitsuste asjaajamiskeel on eesti keel.

Kuna põhiseaduse preambul on aluseks põhiseadusele kui tervikule (EVPKV 2002), peab eesti keele kasutamine lisaks riigi ja kohaliku omavalitsuse asjaajamisele ja haridusele olema tagatud ka teistes valdkondades, kus põhiseadus otsesõnu eesti keelt ei nimeta. Kindlasti tuleb siin mainida põhiseaduse $\S 28$, mille kohaselt on igaühel õigus tervise kaitsele. Selle sätte alusel oleks loogiline eeldada, et Eesti Vabariigis on tagatud eestikeelne tervishoiuteenus. Samuti on oluline $\S 44$, mille kohaselt on igaühel õigus saada üldiseks kasutamiseks levitatavat teavet. See tähendab, et kogu avalikkusele suunatud teave, nii see, mida annavad riik ja kohalikud omavalitsused, kui ka see, mida jagavad eraõiguslikud institutsioonid (tarbijateave, reklaam, ettevõtete teadaanded jms), peab olema kättesaadav eesti keeles.

Peale põhiseaduse leidub keelekasutust reguleerivaid norme enam kui sajas seaduses, valitsuse määruses ja muus õigusaktis. Keeleseaduses on esitatud keelekasutuse üldised põhimõtted, mida täpsustatakse eri valdkondi reguleerivates seadustes, nagu nt kodakondsuse seadus; kohaliku omavalitsuse korralduse seadus; avaliku teenistuse seadus; tarbijakaitseseadus; haridusseadus ja eri haridusasutuste (koolieelsed lasteasutused, põhikoolid ja gümnaasiumid, rakenduskõrgkoolid, ülikoolid, kutseõppeasutused, erakoolid) tegevust reguleerivad seadused; kohtute, prokuratuuri ja advokatuuri tegevust reguleerivad seadused;

1 Põhiseaduse preambulis seatud eesmärk tagada eesti rahvuse, s.t eesti rahvusest inimeste säilimine on tekitanud poliitikute hulgas vaidlusi. Ühe tõlgendusena on pakutud, et põhiseaduses pole silmas peetud mitte eesti rahvusest inimesi, vaid kõiki Eestis elavaid inimesi ehk Eesti rahvast, vt Ministri suhtumine põhiseaduse preambulisse, http://stenogrammid.riigikogu.ee/et/201606011300\#PKP-19030. 
haldusmenetluse seadus; kriminaalmenetluse seadustik; märgukirjale ja selgitustaotlusele vastamise ning kollektiivse pöördumise esitamise seadus jpm õigusaktid.

Praegune õiguskantsler, toonane Tartu Ülikooli riigiõiguse professor Ülle Madise arutles 2015. aastal tööandjate aastakonverentsil "Tuulelohe lend” selle üle, mis juhtuks, kui Riigikogu ei võtaks aasta jooksul vastu mitte ühtegi seadust. Tema sõnul ei juhtuks mitte midagi. Pidevaid seadusemuudatusi võrdles ta olukorraga, kus kraani või pliidi parandamiseks remonditakse ära kogu maja. "Hädavaevu on tolm maha langenud ja värvilõhn lahtunud, kui juba leitakse kehv ukselink ning juba läheb täisremont uuesti lahti," kirjeldas Ülle Madise (Madise 2015).

Kui seda mõttekäiku keelepoliitika ja keelekasutust reguleerivate õigusaktide kontekstis vaadelda, siis võib tõepoolest öelda, et uute õigusaktide vastu võtmata jätmine ei muudaks mitte midagi, küsimus on aga selles, kas praegune olukord meid rahuldab.

Viidatud ettekandes väitis professor Madise ka seda, nagu oleks põhiseadus kohati ülemäära detailne. Arvestades asjaolu, et väljatöötamisest ja vastuvõtmisest möödunud aja jooksul on põhiseadust muudetud või täiendatud viiel korral, kusjuures muudetud ei ole mitte detaile, vaid üsnagi põhimõttelist laadi riigielu küsimusi, siis võib pigem asuda seisukohale, et meie põhiseaduses on riigi ja ühiskonna toimimise alused piisava üksikasjalikkusega paika pandud.

Alljärgnevalt vaatlen keelepoliitika aluspõhimõtteid põhiseaduses ning seda, kuidas neid õigusaktides ja tegelikkuses rakendatud on. Peatähelepanu pööran kolmele valdkonnale, milleks on eesti keel riigi ja kohaliku omavalitsuse asjaajamises, eesti keel hariduses ning eesti keel tervishoius.

Keelepoliitika tõhususe hindamisel lähtun keeleseaduse täitmise analüüsist ning järelevalvepraktikas kerkinud probleemidest, püüdes välja selgitada, kas keeleseaduses ja valdkondlikes seadustes ning erinevates rakendusaktides on kõik põhiseaduse võimalused ära kasutatud või on seadusandja või täidesaatev võim teinud keelepoliitika aluspõhimõtete rakendamisel põhjendamatuid järeleandmisi. Vaatlen ka seda, kuidas valdkonna õigusaktid, nende vastuvõtmine ja muutmine on mõjutanud Eesti keeleolukorda. 


\section{Eesti keel riigi ja kohaliku omavalitsuse asjaajamises}

Keelepoliitika seisukohalt kõige olulisem on põhiseaduse kõige lühem paragrahv, milleks on $\S 6$, "Eesti riigikeel on eesti keel".

Võib liialdamata öelda, et riigikeele määramine on keelepoliitika nurgakivi. On mitmeid ajaloolisi, poliitilisi ja demograafilisi põhjendusi, miks mitmekeelses ja -rahvuselises Eestis on põhiseaduse kohaselt vaid üks riigikeel. Nende põhjenduste üle arutlemine ei ole käesoleva artikli eesmärk.

Riigikeele mõistet on selgitatud nii sõnaraamatuis kui ka muudes teatmeteostes selle mõistega hõlmatud objektide loetelu kaudu: asjaajamise, hariduse, teeninduse ja teabe kohustuslik, seadusaktiga määratud töökeel (EE).

Keelepoliitika tõhusus sõltub sellest, kui hästi riigikeel eespool nimetatud valdkondades oma funktsioone täidab: kas õiguslik mehhanism on küllaldane, et tagada keele kasutamine eespool nimetatud ametliku ja avaliku elu valdkondades; kas keele arendamiseks ja kaitseks on loodud vajalikud tingimused, mis on riigikeele funktsioonide täitmise eelduseks; kuidas hoitakse riigikeele mainet ja kuidas suudetakse korraldada nii emakeeleõpet haridussüsteemis kui ka riigikeeleõpet täienduskoolitusena neile, kelle emakeel ei ole eesti keel.

Paragrahviga 6 on eesti keel määratud ka põhiseaduses loetletud põhiseaduslike institutsioonide töö- ja asjaajamiskeeleks - isegi sellistel juhtudel, kus seda otsesõnu nimetatud ei ole. Need juhtumid, kus üldistest inimõigustest või vähemusrahvuse keeleõigusest tulenevalt tuleb kasutada teisi keeli, on põhiseaduses eraldi ära märgitud (nt $\S 21$, 51,52 ).

Esimesena on põhiseaduslikest institutsioonidest nimetatud Riigi$\operatorname{kogu}^{2}$. Põhiseaduse $\S 59$ sätestab, et seadusandlik võim kuulub Riigikogule.

Riigikogu kodu- ja töökorra seaduse $\S 158 \lg 1$ kohaselt on Riigikogu asjaajamiskeel eesti keel. Lõigetes 2 ja 3 täpsustatakse, et eelnõud, arupärimised ja muud dokumendid esitatakse eesti keeles ning

2 Olgu kõrvalmärkusena öeldud, et Riigikogu on Eesti seadusandliku kogu nimi ja see kirjutatakse suure algustähega. Märkus on tingitud algustähe õigekirja teemal peetud arutelust keelekorraldajatega, kes soovitavad käsitada sõna Riigikogu liigisõnana ja kirjutada seda väikese algustähega. Põhiseaduses ja keeleseaduses seevastu on sõnaselgelt kirjas, et tegu on seadusandliku kogu nimega, mis tuleb kirjutada suure algustähega nagu kõik muudki nimed ja nagu seda ongi tehtud põhiseaduses ja keeleseaduses ning kõigis muudes õigusaktides. 
ettekanded ja sõnavõtud peetakse ning küsimused esitatakse ja neile vastatakse eesti keeles. Siiski ei tähenda see, et Riigikogu saalis ei tohiks kõlada mõni teine keel peale eesti keele või ei tohiks Riigikogu liikmed oma ülesandeid täites kasutada võõrkeeli. Riigikogu külalised võivad Riigikogus esineda neile sobivas keeles, kuid Riigikogu koduja töökorra seaduse $\S 13$ lõike 2 punkti 7 kohaselt tuleb selleks enne Riigikogu juhatuselt luba taotleda. Sama seaduse kohaselt esitatakse välislepinguid käsitlevad seaduseelnõud koos lepingu eesti- ja võõrkeelse tekstiga. Kui välislepingu algtekst on ainult võõrkeeles, esitatakse ka lepingu tõlge eesti keelde, et oleks tagatud võimalus lepinguga seonduvat eesti keeles menetleda. Vähemusrahvuse keele kasutamine ei ole välistatud ka Riigikogu fraktsioonis, nt kui tegu on seda vähemusrahvust esindava fraktsiooniga ja kui selline on fraktsiooni liikmete omavaheline kokkulepe. Kuid kõik, mida Riigikogus või rahvaesindajana riigiasju ajades Riigikogu istungitel või komisjonides võõrkeeles räägitakse, peab olema kättesaadav ka eesti keeles.

Seadusi menetletakse ning need võetakse vastu ja avaldatakse eesti keeles. Eestis kehtivad õigusaktid eesti keeles. Loomulikult võib neid tõlkida teistesse keeltesse, et teha need arusaadavaks ka muid keeli rääkivatele inimestele.

Eespool kirjeldatud Riigikogu asjaajamiskeele regulatsioon jõudis Riigikogu kodu- ja töökorra seadusesse 2001. aastal pärast seda, kui Riigikogu võttis vastu otsuse jätta Riigikogu valimise seadusest ning kohaliku omavalitsuse volikogu valimise seadusest välja neisse organitesse kandideerijate eesti keele oskuse nõue. Saadikukandidaatide keelenõude põhiseaduspärasuse üle toimus pikk arutelu ja mitu kohtuvaidlust (kohtuasi 3-4-1-1-98; kohtuasi 3-4-1-7-98).

Riigikeele oskuse nõue Riigikogu liikmetele ja kohaliku omavalitsuse volikogu liikmetele kehtestati 1995. aastal vastu võetud keeleseaduse muudatusega, millega sätestati eesti keele oskuse nõue Riigikogu ja kohaliku volikogu liikmetele ning volitati Vabariigi Valitsust välja töötama vastava keeleoskustaseme kirjeldus (Tomusk 2002). Hiljem viidi poliitikute keelenõue põhiseaduslikesse seadustesse, sest eespool viidatud Riigikohtu põhiseaduslikkuse järelevalve kohtukolleegiumi otsuse kohaselt ei saa keeleseadusega, mis on lihtseadus, reguleerida põhiseaduslike institutsioonide tegevust puudutavaid küsimusi. Keelenõudest aga poliitikuid siis veel ei vabastatud. Riigikohtu otsuses rõhutati, et keelenõuded tuleb sätestada vastavates valimisseadustes, sest rahvaesindajate töö eeldab väga head keeleoskust ja see on demokraatia toimimiseks absoluutselt vajalik. 
15. detsembril 1998 vastu võetud Riigikogu valimise seaduse, kohaliku omavalitsuse volikogu valimise seaduse ja keeleseaduse muutmise ja täiendamise seadusega (Riigikogu 1999) lisati Riigikogu valimise seadusesse paragrahv $2^{1}$, milles esitati keeleoskuse kirjeldus. Riigikogu liikme suuline ja kirjalik eesti keele oskus pidi võimaldama tal osa võtta Riigikogu tööst. Ta pidi olema võimeline mõistma õigusaktide ja teiste tekstide sisu, tegema ettekandeid päevakorras olevates küsimustes ning avaldama oma arvamust kõne ja sõnavõtu vormis, esitama arupärimisi ja küsimusi, tegema ettepanekuid ning suhtlema valijatega, vastama pöördumistele, avaldustele ja järelepärimistele. Kohaliku omavalitsuse volikogu valimise seadusesse sama seadusemuudatusega lisatud paragrahv $3^{1}$ esitas sellesama nõude ka kohaliku volikogu liikmetele.

Poliitikute keelenõude küsimus kerkis taas 2001. aasta teisel poolel, kui 15. oktoobril algatasid kolm valitsuskoalitsiooni esindavat Riigikogu liiget seaduseelnõu saadikute keelenõude tühistamiseks, nimetades seda nii isiklikuks veendumuseks kui ka vajalikuks tingimuseks, et lõppeks OSCE missiooni tegevus Eestis, mis olevat peamine takistus Eesti liitumisel Euroopa Liidu ja NATO-ga. Pärast paarinädalast vaidlust kaotaski Riigikogu 21. novembril 2001 keelenõude (Riigikogu 2001). Olgu lisatud, et Lätis jäi poliitikute keelenõue kehtima (Läti valimisseadus), ometi lõpetas OSCE missioon oma tegevuse 2001. aasta detsembris nii Eestis kui ka Lätis.

Seega ei pea kohaliku volikogu ega Riigikogu liige eesti keelt oskama, kuid peab seda kasutama kõigis volikogu või Riigikogu töövormides. Kas ja kuidas saadikute keelenõude kaotamine on mõjutanud Eesti keeleolukorda üldiselt ja eri piirkondades? Riigikogu suuline ja kirjalik asjaajamine on kindlalt eestikeelne, v.a eespool kirjeldatud võoorkeelte kasutamise juhtumid, mis aga ei ole kuidagi seotud Riigikogu liikmete ebapiisava eesti keele oskusega. Seevastu mitmes Ida-Virumaa kohalikus omavalitsuses (Narva, Sillamäe, Narva-Jõesuu) on eesti keele kasutamine asjaajamises veel praegugi suures osas formaalne just volikogu liikmete kasina eesti keele oskuse tõttu. Keelenõude kaotamine on süvendanud arusaama, et omavalitsuspoliitikas on võimalik osaleda ka ilma eesti keelt oskamata. Tööd tehakse tihti vene keeles ning avalikustamiseks kohustuslikud dokumendid tõlgitakse eesti keelde tagantjärele.

Saadikukandidaatide riigikeeleoskuse nõude kaotamisel on Eesti keelepoliitikale märksa suurem mõju, kui seda võiks potentsiaalsete kandideerijate arvu järgi eeldada. Tegemist on keelepoliitika aluspõhimõtet muutva otsusega, mis ei soodusta demokraatia toimimist ega toeta riigi integratsioonipoliitikat. Siiski ei ole päriselt täide läinud 
Sillamäe kunagise linnapea ennustus, kes 1996. aastal ETV uudistesaates kinnitas venekeelse asjaajamise jätkumist Sillamäe linnavalitsuse ja volikogu töös: "Tak bõlo, jest i budet"3 (Tomusk 2004a).

Sillamäel valdab juba õige mitmes linnapea eesti keelt emakeelena ja ka linnaametnike hulgas on eesti keele oskus paranemas nii Sillamäel kui ka teistes venekeelse enamusega omavalitsustes.

Ootamatu tagasilöögi sai aga vallavanema, linnapea ja valitsuse liikme eesti keele oskuse nõue pärast uue avaliku teenistuse seaduse jõustumist 1. aprillil 2013. Kuni selle ajani kuulusid nimetatud kohaliku omavalitsuse juhid ametnike hulka, kellelt keeleseaduse alusel nõuti eesti keele oskust kõrgtasemel (tase C1). Uue seaduse järgi ei ole linnapea, vallavanem või valitsuse liige enam ametnikud ning seetõttu ei kehti nende suhtes ka ametnike keelenõue.

Kuigi seadusandja eesmärk ei olnud vallavanemat, linnapead ega vallavalitsuse liiget eesti keele oskuse nõudest vabastada, võimaldas tõenäoliselt tähelepanematusest tekkinud seaduslünk tõlgendust, nagu nimetatute suhtes ei kehtiks keeleseaduse alusel kehtestatud keeleoskusnõuded. Segaduse kõrvaldamiseks täiendati alles kahe aasta möödudes kohaliku omavalitsuse korralduse seaduse $\S 48^{2}$ esimest lõiget muudatusega, mis sätestab, et vallavanem, linnapea ja valitsuse liige peab valdama eesti keelt keeleseaduses ja keeleseaduse alusel kehtestatud õigusaktides ametnikule esitatud nõuete ulatuses, seega tasemel C1. Sellega leidsid lahenduse ka õiguslikud vaidlused, mis keeleinspektsioonil olid tekkinud ebapiisava eesti keele oskusega linnajuhtide (nt Maardu linnapea, Paldiski abilinnapea) eesti keele oskuse nõude täitmise järelevalves. Muudatus jõustub siiski alles 1 . novembril 2017.

Praegu vastab kõigi linnapeade ja vallavanemate eesti keele oskus nõutavale tasemele, kuid paljude Narva ning Sillamäe linnaametnike ja volikoguliikmete eesti keele oskus ei ole piisav selleks, et oleks tagatud eestikeelne asjaajamine, mis annaks nimetatud kohalikele omavalitsustele võimaluse kasutada vastavalt põhiseaduse $\S$-le 52 sisemises asjaajamises eesti keele kõrval vene keelt. Keeleseaduse $\S 11$ sätestab põhiseaduse $\S 52$ teises lõikes nimetatud keele kasutamise ulatuse ja korra täpsustamiseks, et paikkonna püsielanike enamiku keelt võib kasutada sisemises asjaajamises eesti keele kõrval, kui Vabariigi Valitsus on selleks oma nõusoleku andnud.

3 Nii oli, on ja jääb. 
Nii Narva kui ka Sillamäe volikogu ongi pöördunud mitmel korral Vabariigi Valitsuse poole ettepanekuga lubada kasutada kohaliku omavalitsuse sisemises asjaajamises eesti keele kõrval vene keelt (Tomusk 2004a). Vabariigi Valitsus on nende paikkondade keeleolukorra analüüsi tulemusel taotlused tagasi lükanud põhjendusel, et venekeelse sisemise asjaajamise seadustamine, ilma et oleks tagatud eestikeelne asjaajamine, viiks eesti keele väljatõrjumiseni linna asjaajamisest ning vähendaks linnaametnike ja munitsipaalasutuste töötajate, sh koolijuhtide ja pedagoogide eesti keele õppe motivatsiooni.

Kõigis teistes põhiseaduslikes institutsioonides on eestikeelne asjaajamine kindlalt tagatud (inglise keele kasutamine erasuhtluses, nt Twitteris, ei ole käsitatav põhiseadusliku institutsiooni asjaajamisena). Kui keeleinspektsiooni, aga eriti selle eellase keeleameti tegevuse algusaastatest võib meenutada nii kohtunike, prokuröride kui ka ministeeriumide või nende valitsemisala asutuste ametnike keeleoskuse kohta laekunud kaebusi ja nende kontrollimist, siis praegu võib üsna kindel olla, et nimetatud ametiasutuste ametnikud valdavad eesti keelt nõutaval tasemel. Politsei- ja päästeametnike eesti keele oskusega on muret veel Ida-Virumaal, kuid viimaste aastate kontrollid näitavad, et isegi Ida-Virumaal ei ole enam ühtegi politseiametnikku, kes üldse eesti keelt ei oskaks (kuigi nõutava C1-tasemeni on paljudel veel pikk tee minna). Aastaid mureks olnud vanglaametnike eesti keele oskuse probleem sai lahendatud lühikese ajaga ja resoluutselt: vanglaametnikele määrati tähtaeg C1-tasemel eesti keele oskuse omandamiseks ja kes selle aja jooksul nõutavat eksamit ära ei teinud, vabastati ametist.

\section{Eesti keel hariduses}

Eesti keele kui riigikeele staatuse kindlustamise ja selle tõhusa toimimise eelduseks on kõigi Eesti elanike eesti keele oskuse edendamine. On ootuspärane, et riiklik haridussüsteem - isegi sel juhul, kui mõnes koolis toimub õpe muus keeles - annab lõpetajatele piisava eesti keele oskuse ühiskonnaelus toimetulekuks. Meie vene õppekeelega kool ei ole seda ootust täitnud, seepärast väärib hariduse valdkond lähemat analüüsi.

Sätestades põhiseaduse paragrahv 37 esimeses lõikes igaühe õiguse haridusele, öeldakse lõikes 4 , et igaühel on õigus saada eestikeelset õpetust ning et vähemusrahvuse õppeasutuses valib õppekeele õppeasutus. Hariduse kättesaadavaks tegemiseks peavad riik ja kohalikud omavalitsused ülal vajalikul arvul õppeasutusi. Seaduse alusel võib 
avada ja pidada ka muid õppeasutusi, sh erakoole $e^{4}$. Oluline on ka selle paragrahvi viimane lõige, mis ütleb, et hariduse andmine on riigi järelevalve all. Kuivõrd tulemuslik on olnud riigi tegevus eesti keele õppe kvaliteedi tagamisel, sellest allpool lähemalt.

Põhiseaduse 37. paragrahvi kohta tuleks teha veel kaks märkust. Esiteks tähendab igaühe õigus saada eestikeelset õpetust seda, et see õigus kehtib nii eestlastele kui ka kõikidele teistele Eestis elavatele rahvustele. Teiseks tuleb rõhutada, et vähemusrahvuse õppeasutuse all ei peeta silmas mitte võõrkeelset õpetust andvat munitsipaalkooli, vaid vähemusrahvuse kultuuriautonoomia seaduse ja erakooliseaduse alusel tegutsevat ja vähemusrahvuse keelset või rahvuskultuuri süvaõppega kooli, mille asutajaks on vähemusrahvuse kultuuriomavalitsus.

Praeguseks on oma kultuuriomavalitsuseni jõudnud vaid kaks vähemusrahvust: ingerisoomlased (2004) ja eestirootslased (2007), seevastu venelased ja teised venekeelsed rahvusrühmad ei ole oma kultuuriomavalitsuse loomist vajalikuks pidanud. See on ka arusaadav, sest kultuuriomavalitsuse üks peamisi ülesandeid on omakeelse koolihariduse edendamine. Eesti riik aga edendab venekeelset haridust märksa suuremas ulatuses, kui seda kavandati Eesti Vabariigi iseseisvuse taastamise järel või kui seda nõuaksid Euroopa Nõukogu vähemusrahvuste õigusi reguleerivad konventsioonid (Raamkonventsioon) või OSCE soovitused (Haag 1996).

Kuna hariduse keel on eesti keel, on iseenesest mõistetav, et nii haridusasutuste juhid kui ka õpetajad oskavad oma tööülesannete täitmiseks vajalikul tasemel eesti keelt. Keeleseaduse alusel peavad muus keeles õpetavad pedagoogid (sh lasteaiaõpetajad) oskama eesti keelt vähemalt B2-tasemel, eesti keele või eesti keeles õpetavad pedagoogid, koolijuhid ja nende asetäitjad aga C1-tasemel. Praegu see paraku nii ei ole.

Nõukogude ajast meile pärandiks jäänud venekeelsel haridussüsteemil oli eesti kooliga väga vähe ühist, õpiti üleliiduliste õppeprogrammide järgi ning õpetajadki olid hariduse saanud väljaspool Eestit (ENSV-d). Selle lõhe ületamine ja ühtse haridussüsteemi loomine ei ole siiamaani õnnestunud, kuigi juba 1993. aastal võeti vastu põhikoolija gümnaasiumiseadus (PGS), mille $§ 52 \mathrm{lg} 2$ sätestas eestikeelsele

4 Erakooliseaduse $\S 15 \lg 1$ kohaselt määratakse õppekeel kooli põhikirjas, kusjuures $\lg$-s $1^{1}$ täpsustatakse, et gümnaasiumi õppekeele määramisel lähtutakse põhikooli- ja gümnaasiumiseadusega kehtestatud nõuetest, kui gümnaasiumi pidaja osanik, aktsionär, asutaja või liige on riik või kohalik omavalitsus. Sama paragrahvi lõigetes 2 ja 3 sätestatakse nõuded eesti keele õppele erakoolides, kus õppekeel ei ole eesti keel. 
õppele ülemineku alguseks aasta 1993, lõpptähtajaks seati aasta 2000 (Tomusk 2004b). Seega nägi seadusandja ette, et aastaks 2000 lõpetavad venekeelsed koolid Eestis oma tegevuse. Esimestel üleminekuaastatel konkreetseid tegevuskavasid välja ei töötatud. Sajandivahetuse lähenedes märgati, et vene kool iseenesest eestikeelseks ei muutu, ning 1997. aastal täiendati PGS-i mitme olulise sättega, mis pidid looma üleminekuks konkreetsed eeldused: muukeelse põhikooli õppekava ja koolikorraldust kohustati tagama aastaks 2007 kõigile põhikooli lõpetajatele eesti keele oskus tasemel, mis võimaldab jätkata õpinguid eesti keeles. Samuti sätestati, et riigi- ja munitsipaalgümnaasiumides alustatakse üleminekut eesti õppekeelele hiljemalt 2007/2008. õppeaastal.

Uues, 2010. aastal vastu võetud PGS-is enam üleminekust ei räägita, vaid sätestatakse üldnormina, et õppekeeleks loetakse keel, milles õpetatakse vähemalt $60 \%$ õppekavas määratud õppekoormusest. Haridusteoreetikute arvates annab see õpilastele piisavalt hea eesti keele oskuse ja võimaldab säilitada ka emakeele. Haridus- ja Teadusministeeriumi kodulehel 2015/2016. õppeaasta kohta käivates andmetes vene õppekeelega gümnaasiume ei nimetata, EHIS-es õppekeele alusel gümnaasiume otsides leiab siiski 32 gümnaasiumi, kus (ilmselt siis seadusega lubatud $40 \%$ ulatuses) kasutatakse õppetöös vene keelt.

Vene õppekeelega koolide ja lasteaedade õpetajate eesti keele oskuse kontrolli tulemused annavad alust arvata, et nii nagu mõne kohaliku omavalitsuse volikogu asjaajamises, on ka mõnes koolis eesti keele kasutamine õppetöös suuresti formaalne ning eesti keeles toimuvates tundides võtab aineõpetaja appi vene keele, kui eestikeelsete selgituste andmisega hätta jääb.

Mitu uuringut on näidanud (Metslang 2013), et osa vene kooli õpetajatest ja koolijuhtidest peab eestikeelsele õppele üleminekut läbimõtlematuks ja süsteemituks; poliitiliselt heitlik olukord selle ümber põhjustab nende hinnangul konflikte ega soodusta sisulist dialoogi. Keeleinspektsiooni järelevalvetulemuste põhjal on alust arvata, et sellise hoiaku põhjus on eeskätt aineõpetajate ja koolijuhtide ebapiisav eesti keele oskus.

Üheks põhjuseks, miks eesti keel vene koolis nii vaevaliselt kanda kinnitab, on see, et seadusandja on üleminekut eesti õppekeelele pika aja vältel edasi lükanud ning andnud ka õppekeele mõistele suhteliselt vaba tõlgenduse.

PGS-i kohaselt on muu õppekeelega koolis eesti keele õpe kohustuslik koolieelsest lasteasutustest kuni gümnaasiumi lõpuni välja, kusjuures kooli lõpetamisel peab õpilane oskama eesti keelt sellisel tasemel, mis võimaldaks põhikooli lõpetajatel jätkata õpinguid eesti õppekeelega 
õppeasutuses. Tegelikust elust aga võib tuua küllalt näiteid selle kohta, et see eesmärk on jäänud saavutamata: gümnaasiumi lõpetajad, kes on $60 \%$ ainetest õppinud eesti keeles, sisenevad tööturule ebapiisava eesti keele oskusega. Needsamad gümnaasiumiõpilased, kes eesti keele ainekava kohaselt veedavad eesti keelt kui õppeainet õppides enam kui 1000 koolitundi (sellele lisanduvad kohustuslikud eestikeelsed õppeained), käivad koolitundidele lisaks tasulistel eesti keele kursustel, et kooli lõpetamiseks nõutavat tasemeeksamit teha.

Kui õpilaste keeleoskuse probleemid gümnaasiumi lõpuks ei lahene, siis kanduvad need koos lõpetajatega kõrgkooli, kus ollakse sunnitud ebapiisava keeleoskusega üliõpilastele otsima võimalusi õppida eesti keelt süvendatult kas erialaõpingutega paralleelselt või siis lõimitud aine- ja keeleõppe vormis. Kõrghariduses aga pakub eesti keelele tugevat konkurentsi inglise keel, ingliskeelse õppe võimaluste laienemine võib vene koolist tulijatel aga tekitada küsimuse, milleks üldse eestikeelset haridust vaja on (Klaas 2012).

Seega võib öelda, et põhiseaduslik õigus saada eestikeelset õpet üldhariduskoolis ei ole kõigile vene õppekeelega koolide õpilastele tagatud. Seda, et tegemist ei ole pelga poliitilise loosungi, vaid vajadusega, kinnitavad uuringud, mille kohaselt peavad vene emakeelega lapsevanemad eestikeelse hariduse omandamist oluliseks, kuid vene õppekeelega koolides töötavate õpetajate ebapiisav eesti keele oskus seda ei toeta (HTM 2015).

Siingi tundub peamine põhjus olevat eestikeelsele õppele ülemineku ümber tekitatud õiguslikus segaduses, ülemineku tähtaegade pidevas edasilükkamises ja võetud otsuste täitmata jätmises, mis omakorda tuleb keele- ja aineõppeks küllaldase eesti keele oskusega õpetajate vähesusest.

Võrreldes paari aastakümne taguse ajaga on olukord eesti keele õpetajatega siiski tunduvalt paranenud. Kui keeleamet uuris 1990. aastate alguses haridusministeeriumist saadud andmeid vene koolide eesti keele õpetajate erialase ettevalmistuse kohta, siis selgus, et selles vallas tegutses tervelt 44 eriala esindajaid alates eesti ja muudest filoloogidest ja lõpetades mesiniku, meremehe, loomaarsti ja õmblustehnoloogiga. Õppeasutuste nimekiri, kus eesti keele õpetaja oli kõrghariduse diplomi saanud, oli samuti nii geograafiliselt kui ka tegevusaladelt mitmekülgne: Moskva, Leningrad, Samarkand, Taganrog; ülikool, pedagoogikainstituut, elektrotehnikainstituut, polütehnikum ja kehakultuuriinstituut on mõned eredamad näited. Sootuks teine pilt avanes, kui keeleametnikud kontrollisid aastail 2013-2014 vene koolide eesti keele ja eesti keeles õpetavate õpetajate eesti keele oskust. Siis selgus, et jätkuvalt on probleeme vaid Ida-Virumaal, kus 231 eesti keeles õpetava õpetaja 
seas tuvastati 47 nõuetele mittevastava eesti keele oskusega õpetajat (Narvas 28, Kohtla-Järvel 9 ja Sillamäel 10). Tallinnas oli 3 ja Tartus 2 ebapiisava keeleoskusega õpetajat.

Mujal Eestis tegutsevates vene õppekeelega gümnaasiumides (Pärnu, Kallaste, Räpina, Mustvee) vastas kõigi õpetajate eesti keele oskus kehtestatud tasemele, kusjuures suurem osa nimetatud koolide õpetajaist on omandanud tasemehariduse eesti keeles.

Need andmed sisendavad lootust, et eesti keele õppe tase koolides siiski paraneb. Samas on jätkuvalt probleeme aineõpetajatega. 2016. aastal koostatud järelevalveandmete analüüs näitab, et Ida-Virumaa linnades (Narva, Sillamäe, Jõhvi, Kohtla-Järve) on kokku 1265 nõuetele mittevastava eesti keele oskusega haridustöötajat, neist õpetajaid koguni 913. Keeleinspektsiooni paljude aastate järelevalvetulemused on näidanud, et pedagoogid on võrreldes teiste valdkondade töötajatega kehvemad keeleõppijad, ettekirjutuse sooritada tasemeeksam täidab keskeltläbi üks neljandik ettekirjutuse saanutest. Mõnikord jääb koguni mulje, et politseinike, aga eriti vanglaametnike eesti keele oskus on paranenud tunduvalt kiiremini kui kooli- või lasteaiaõpetajate oma. Kindlasti ei ole põhjus selles, et politsei- või vanglaametnikud oleks pedagoogidest usinamad või andekamad keeleõppijad. Pigem on asi õpimotivatsioonis, mille tekitamine või kadumine on suuresti tööandja kätes, kuid mida kindlasti mõjutab ka õigusruum.

Keeleseaduse kohaselt tagab tööandja (vaadeldaval juhul kooli- või lasteaiadirektor), et töötajad, kellele on keeleoskuse nõue kehtestatud, valdavad eesti keelt nõutaval tasemel. Ida-Virumaal, kus veel hiljaaegu oli koolidirektoritel endilgi eesti keelega raskusi, ei olnud nad tihtipeale võimelised õpetajate eesti keele oskuse taset hindama.

Ida-Virumaal annab tunda ka kooli pidaja, s.t kohaliku omavalitsuse ükskõikne suhtumine koolijuhtide eesti keele oskusesse. Millegi muuga on raske põhjendada Narva Linnavalitsuse otsust kaevata kohtusse (kohtuasi 3-12-1071) keeleinspektsiooni ettekirjutus, millega nõuti kohalikult omavalitsuselt, et see tagaks koolijuhtide keeleoskuse keeleseaduse alusel sätestatud tasemel. Vaidlus läbis kõik kohtuastmed ja lõppes sellega, et Riigikohus ei võtnud Narva kassatsioonkaebust menetlusse. Narva Linnavalitsus tasus talle määratud sunniraha, kuid jättis keeleoskamatud direktorid ametisse. Sellel on otsene mõju ka kogu koolipere suhtumisele eesti keele õppesse.

Koolijuhtide keelenõude vastu võitlemisel võttis Narva Linnavalitsus appi ka tuntud advokaadibüroo. Narva Linnakantselei juriidiliste kulude päevaraamatu andmetel tasuti keeleinspektsiooni ettekirjutuse 
vaidlustamise asjas linnavalitsust kohtus esindanud advokaadibüroole 2012. aasta jooksul 9682, 95 eurot (Narva 2012).

\section{Eesti keel tervishoius}

Eesti Vabariigi põhiseaduse $\S 28$ lõige 1 ütleb, et igaühel on õigus tervise kaitsele. See tähendab, et tervise kaitse on inimese põhiõigus ning riigi kohus on tagada tervishoiusüsteemi tõhus toimimine. Kuna Eesti riigikeel on eesti keel ning riigi ülesanne on eesti rahvuse, keele ja kultuuri säilimine läbi aegade, peab igaühele olema kättesaadav eestikeelne tervishoiuteenus (Tomusk 2016).

Keeleinspektsiooni viimaste aastate järelevalvetulemused aga näitavad, et eestikeelse tervishoiuteenuse kättesaadavusega on mõnes Eesti piirkonnas üsna suuri probleeme.

2012. aastal kontrolliti 226 töötaja (arstid, meditsiiniõed, proviisorid, farmatseudid, hooldustöötajad) eesti keele oskust, kusjuures tuvastati 183 ilma nõutava keeleoskuseta töötajat. 2013. aastal kontrolliti 725 töötaja eesti keele oskust, tuvastati 519 ilma nõutava keeleoskuseta töötajat. 2014. aastal kontrolliti 94 töötaja eesti keele oskust, tuvastati 91 ilma nõutava keeleoskuseta töötajat. 2015. aastal kontrolliti 45 töötaja eesti keele oskust, tuvastati 37 ilma nõutava keeleoskuseta töötajat. Seega tuvastati umbes $80 \%$-1 kontrollitud tervisevaldkonna töötajaist puudulik eesti keele oskus. Peamiselt on tegemist Ida-Virumaal tegutsevate haiglate töötajatega, kuid kontrollitute hulgas oli ka muudes Eesti piirkondades tegutsevaid farmatseute, perearste, meditsiiniõdesid ning hooldajaid. Inspektsiooni järelkontrollidest selgub, et ettekirjutuse sooritada nõutav tasemeeksam on täitnud umbes $30 \%$ töötajaist.

Keeleseaduse alusel kehtestatud valitsuse määruse "Ametniku, töötaja ning füüsilisest isikust ettevõtja eesti keele oskuse ja kasutamise nõuded" $§ 9$ punkt 8 sätestab, et arstidelt nõutakse keeleoskust vähemalt C1-tasemel. Meditsiiniõdedelt nõutakse sama määruse $\S 8 \mathrm{p} 9$ kohaselt B2-tasemel eesti keele oskust. Nii C1-tasemel kui ka B2-tasemel keeleoskus võimaldaks meditsiinitöötajal patsientidega üsna vabalt suhelda. Milles siis on küsimus, miks meditsiinitöötajate keeleoskus on nii kehv?

Hariduse omandanud arstist või õest saab tervishoiutöötaja alates hetkest, kui ta on kantud tervishoiutöötajate riiklikusse registrisse. Tervishoiuteenuste korraldamise seaduse (TTKS) § 27 lg 1 sätestab, et registreerimine annab tervishoiutöötajale õiguse osutada tervishoiuteenuseid kvalifikatsiooni tõendavas dokumendis ja registreerimisel 
väljastatavas registreerimistõendis märgitud kutse või eriala piirides. Seega peaks registrisse kandmine tähendama, et riik on isikule tervishoiuteenuse osutamise õigust andes veendunud, et ta vastab kõikidele õigusaktidega seatud tingimustele.

Riikliku registri ülesanne on sõnastatud TTKS § $27^{1}$ lõikes 2: Tervishoiutöötajate riikliku registri eesmärk on registreerida tervishoiutöötajaid, et tagada tervishoiuteenuse tarbija riiklik kaitse tervishoiuteenuse osutamise kaudu selleks nõutud kvalifikatsiooni omavate isikute poolt ja nende üle järelevalve ning vajalikud andmed valitsusasutustele seadustest ja teistest õigusaktidest tulenevate tervishoiuvaldkonna juhtimise ja korraldamise ülesannete täitmiseks ning tervisestatistika korraldamiseks.

Nii peaks riiklikus registris olema ainult need, kelle eesti keele oskus, mis on arsti kutsekvalifikatsiooni lahutamatu osa, vastab keeleseaduse alusel kehtestatud nõuetele ning kes suudavad patsientidega eesti keeles suhelda. Ometi nähtub inspektsiooni andmetest, et teenust osutavad sajad nõuetele mittevastavad meditsiinitöötajad.

Kui uurida, milliseid andmeid nõuab riik isikult, kes soovib end kanda tervishoiutöötajate riiklikusse registrisse, selgub, et andmeid keeleoskuse kohta ei nõutagi.

TTKS § $28 \lg 2$ alusel kinnitab valdkonna eest vastutav minister registreerimistaotluses esitatavate andmete loetelu. Sotsiaalminister on vastava määruse kinnitanud 2001. aastal, seda on muudetud vaid üks kord 2012. aastal, kui kinnitati uus registreerimistaotluse vorm. Nõutavate andmete hulgas on ees- ja perekonnanimi, sugu ja isikukood (selle puudumisel sünniaasta, -kuu ja -päev), andmed kutse ja eriala kohta, kvalifikatsiooni tõendavad andmed (andmed kutset ja eriala tõendavate dokumentide kohta, töökohad viimasel viiel aastal, elukoht ja muud andmed). Kuid vaatamata sellele, et meditsiinitöötaja peaks olema suuteline töötama eesti keeles ning TTKS räägib tervishoiuteenuse tarbija riiklikust kaitsest, ei soovita teada, kas taotluse esitaja oskab eesti keelt või ei oska.

Loomulikult võib väita, et keeleinspektsioon kontrollib arsti keeleoskust ja teeb vajadusel ettekirjutuse. Samuti võib väita, et eespool nimetatud keelenõuete määruse $\S 3 \lg 3$ sätestab, et töötaja keeleoskusnõude täitmise eest vastutab tööandja. Kuid mida peaks tegema haiglajuht keeleoskamatu arstiga, kellele on registrisse kandmisel kinnitatud, et ta vastab kõigiti tervishoiutöötajale esitatavatele nõuetele? Ning mida peaks mõtlema arst, kelle riik on tunnistanud kõlblikuks, kuid kellele keeleinspektsioon teatab, et tegelikult ei ole tal õigust inimesi ravida? 
Enamik Euroopa riikidest kaitseb oma patsientide õigust suhelda arstiga riigikeeles.

Norras peavad kõik arstid, kes tulevad tööle väljastpoolt Põhjamaid, tegema norra keele 3. astme testi või Bergeni testi (kõrgtase) vähemalt 500-punktilise summaga (maksimum 750) ning läbima suulise suhtluse ja erialakeele kursuse. Erialaeksamid tuleb sooritada norra keeles.

Rootsis valitseb suur arstide ja muude tervishoiutöötajate põud ning uusi töötajaid otsitakse rahvusvaheliste personaliotsingufirmade ja eri veebilehtede kaudu. Saabumisriigist olenemata kehtib kõikidele arstidele ja õdedele rootsi keele oskuse nõue vastavalt C1- või B2-tasemel. Tähtajatu leping arstiga sõlmitakse pärast rootsi keele eksami sooritamist.

Taanis peavad kolmandatest riikidest pärit arstid sooritama 3. taseme taani keele eksami (B2), samuti tuleb sooritada suuline ja kirjalik erialatest, läbida Taani meditsiiniõiguse kursus ja testid, mis kõik toimuvad taani keeles.

Saksamaa korraldab kolmekuulisi (420 tundi, s.t 35 tundi nädalas ehk sisuliselt täistööaeg) keelekursusi inimestele, kes soovivad arstina tööle asuda. Need toimuvad enne erialaeksameid ja dokumentide hindamist, mille käigus tehakse kindlaks, kas taotleja erialane väljaõpe vastab Saksa standarditele. Keelekursuste eesmärk on lihvida erialast saksa keelt, aga ka patsientide, hooldustöötajate ja kaastöötajatega suhtlemise strateegiat.

Kuna Eesti ei nõua tervishoiutöötajatelt registrisse kandmisel eesti keele oskust, siis oleme jõudnud selleni, et meile saabuvad tööle kolmandate riikide arstid, kes eesti keelt ei oska ning kellel on seetõttu patsientide ja kolleegidega suhtlemisel suuri probleeme (Tomusk 2016). Keeleseaduse täitmise järelevalvega ei ole neid probleeme võimalik lahendada, sest keelt paari nädala või kuuga selgeks ei õpi ning kord juba tööle võetud arstil kipub ka õpimotivatsioon langema.

Suurbritannia General Medical Council, meie Terviseameti analoog, on keele tähtsust arsti töös hinnanud järgmiselt: "Kõikidel Suurbritannias praktiseerivatel arstidel peab olema vajalik inglise keele oskus, et nad oleksid võimelised efektiivselt suhtlema ega seaks ohtu oma patsientide turvalisust. Suhtlemine tähendab kõnelemist, lugemist, kirjutamist ja kuulamist" (Medical ...). Sellest tasub Eestil kindlasti eeskuju võtta.

Niisiis, kuigi põhiseaduse $\S 28 \lg 1$ kohaselt on igaühel õigus tervise kaitsele ning asjaomastes õigusaktides on sätestatud tingimused eestikeelse tervishoiuteenuse tagamiseks, raskendavad eestikeelse arstiabi kättesaadavust lüngad madalama astme õigusaktides ning täidesaatva 
võimu tegevusetus ${ }^{5}$ nende lünkade kõrvaldamisel, mis lõppkokkuvõttes seab küsimärgi alla põhiseaduses sätestatud eesmärgi tagada igaühe tervisekaitse.

Kahjuks ei iseloomusta selline järelevalvekeskne keeleoskusnõuete rakendamine ainult tervishoiuvaldkonda. Vaidlus selle üle, kas isik peab teenuse pakkumiseks vajalikku keeleoskust tõendama enne või pärast tegevusloa saamist, toimus 2016. aastal seoses taksojuhtide keeleoskuse probleemiga. Ka siin otsustas Riigikogu, et toetuda tuleks järelevalvele, kuna ühistranspordiseaduse nõue, et tegevusloa taotlemisel peab taksojuht tõendama oma keeleoskust B1-tasemel, tühistati (Riigikogu 2016).

\section{Kokkuvõtteks}

Lähtuvalt põhiseaduse preambulist, milles sõnastatakse põhiseaduse aluspõhimõtted, peab kõik see, mida riik teeb, olgu see siis riigihalduse, hariduse, tervishoiu, aga ka kaitse-, maksu- või keelepoliitika valdkonnas, teenima üht eesmärki - tagada eesti rahvuse, keele ja kultuuri säilimine läbi aegade.

Põhiseaduse keelesätete analüüs näitab, et keelekasutuse põhimõtted on põhiseaduses kirjas piisava selguse ning üksikasjalikkusega, võimaldades täita põhiseaduse preambulis seatud eesmärki. Vaadeldes aga eri valdkondade õigusakte, mis reguleerivad keelekasutust nt kohalikes omavalitsustes, hariduses või tervishoius, tuleb tõdeda, et seal ei ole kas siis seadusandja või täidesaatev võim oma rakendusaktidega põhiseaduse eesmärke piisava täpsusega järginud. Hariduses ja tervishoius on seaduste ja rakendusaktide puudujääke üritatud korvata järelevalvega, kuid praktika näitab, et keelepoliitika heitlikkust (probleemid venekeelses hariduses), õigusaktides esinevaid puudujäk̈ke (rahvasaadikute keeleoskuse nõuded) ning keeleoskuse probleemidest möödavaatamist (tervishoiutöötajate keeleoskus) ei ole võimalik järelevalvemeetmetega korvata.

Kuna käesoleva artikli maht ei võimalda vaadelda ammendavalt kõiki põhiseaduse keelesätetega seonduvaid aspekte, tuleks põhiseaduse analüüsiga kindlasti jätkata. Selle võiks oma ülesandeks võtta 2016. aasta

5 Esmakordselt pöördus keeleinspektsioon meditsiinitöötajate keeleoskust puudutavate regulatsioonide täpsustamise ettepanekuga valitsuse poole 2006. aastal. 2016. aasta Iõpus teatas Sotsiaalministeerium, et ette on valmistatud eelnõu, mille kohaselt nõutaks kolmandate riikide tervishoiutöötajatelt, kes soovivad Eestis praktiseerida, lisaks 2-6-kuulisele tööpraktikale ka seda, et nad läheksid õppima eesti keelt ning esitaksid Terviseametile ka sellekohase tõendi. 
detsembris justiitsministri moodustatud asjatundjate kogu, mille koosseisus on Eesti parimad põhiseaduse asjatundjad ning mille ülesanne on analüüsida Eesti põhiseaduse rakendamisel kerkinud probleeme ja esitada selle kohta vajaduse korral lahendusettepanekud valitsusele.

Põhiseadust analüüsides tuleks valdkondade seadused ning eesti keele oskuse ja kasutamise tagamiseks vajalikud rakendusaktid viia kooskõlla põhiseaduses sätestatud keelekasutuse üldpõhimõtete ning põhiseaduse preambulis sõnastatud eesmärkidega.

\author{
Aadress: \\ Ilmar Tomusk \\ Keeleinspektsioon \\ Endla 4 \\ 10142 Tallinn, Eesti \\ E-post: ilmar.tomusk@keeleinsp.ee
}

\title{
Kirjandus
}

Crystal, David (1992) The Cambridge encyclopedia of language. Cambridge University Press.

EVPKV 2002 = Eesti Vabariigi põhiseaduse kommenteeritud väljaanne. Tallinn: Õigusteabe AS.

Gabrielle Hogan-Brun, Uldis Ozolins, Meilutè Ramonienè, and Mart Rannut (2009) Language politics and practices in the Baltic states, current issues in language planning. Tallinn: Tallinn University Press.

Haag 1996 = Haagi soovitused rahvusvähemuste õiguse kohta haridusele. Foundation on Inter-Ethnic Relations.

HTM 2015 = Analüüs ja ettepanekud eesti keele õppe tõhustamiseks põhikoolis. $<$ https://www.hm.ee/sites/default/files/analuus_ja_ettepanekud_eesti_keele_oppe_ tohustamiseks_pohikoolis.pdf $>$. Vaadatud 18.10.2016.

Klaas-Lang, Birute (2012) "Eesti keele käekäik 21. saj alguses". <https://efo.revues. org/882>. Vaadatud 18.10.2016.

Kohtuasi 3-4-1-1-98 = Riigikohtu põhiseaduslikkuse järelevalve kohtukolleegiumi otsus, Vabariigi Presidendi 30. detsembri 1997. a taotluse, tunnistada Keeleseaduse ja riigilõivuseaduse muutmise ja täiendamise seadus Põhiseadusega vastuolus olevaks, läbivaatamine.

Kohtuasi 3-4-1-7-98 = Riigikohtu põhiseaduslikkuse järelevalve kolleegiumi otsus, Harju Maakohtu taotluse, tunnistada Kohaliku omavalitsuse volikogu valimise seaduse $\S 3$ $\lg 3$ ja $§ 26 \lg 7$ p 1, Keeleseaduse $\S 5 \lg 1$ ning Vabariigi Valitsuse 16. juuli 1996. a määrus nr 188 "Riigikogus ja kohaliku omavalitsuse volikogus töötamiseks vajaliku eesti keele oskuse taseme kirjelduse kehtestamine” osaliselt kehtetuks, läbivaatamine. 
Kohtuasi 3-12-1071 = Tallinna Ringkonnakohtu otsus haldusasjas nr 3-12-1071, Narva linna kaebus keeleinspektsiooni 20. märtsi 2012 ettekirjutus-hoiatuse nr 07-SR-9 tühistamise nõudes.

Läti valimisseadus $=$ The Saeima election law. $<$ http://www.legislationline.org/documents/action/popup/id/3766>. Vaadatud 18.10.2016.

Madise, Ülle (2015) Seadused - kellele ja milleks? Ettekanne tööandjate keskliidu aastakonverentsil "Tuulelohe lend 2015".

$<$ http://kesjulgeb.blogspot.com.ee/2015/02/ulle-madise-seadused-kellele-jamilleks.html>. Vaadatud 12.10.2016.

Medical ... = General Medical Council, English language requirements.

$<$ http://www.gmc-<uk.org/doctors/registration_applications/language_proficiency. asp>. Vaadatud 18.10.2016.

Metslang 2013 = Metslang, Helena, Triin Kibar, Mare Kitsnik, Jevgenia Koržel, Ingrid Krall ja Anastassia Zabrodskaja (2013) Kakskeelne õpe vene õppekeelega koolis. Uuringu loopparuanne. Tallinn: Tallinna Ülikooli Eesti Keele ja Kultuuri Instituut.

Ministri suhtumine põhiseaduse preambulisse, XIII Riigikogu stenogramm, III istungjärk, kolmapäev 01. juuni 2016, 13:10. <http://stenogrammid.riigikogu.ee/ et/201606011300\#PKP-19030>. Vaadatud 18.10.2016.

Narva 2012 = Narva Linnakantselei juriidiliste kulude päevaraamat. $<$ https://dokregister.narva.ee/index.php?page=docshow\&docid=126790>. Vaadatud 18.10.2012.

Põhiseadus 2012 = Eesti Vabariigi Põhiseadus. Riigi Teataja eriväljaanne põhiseaduse 20. aastapäeva tähistamiseks. Riigi Teataja 2012.

Raamkonventsioon $=$ Vähemusrahvuste kaitse raamkonventsioon . $<$ https://www.riigiteataja.ee/akt/13086847>. Vaadatud 18.10.2016.

Riigikogu 1999 = Riigikogu valimise seaduse, kohaliku omavalitsuse volikogu valimise seaduse ja keeleseaduse muutmise ja täiendamise seadus. Riigi Teataja I, 1999, 1, 1.

Riigikogu 2001 = Riigikogu valimise seaduse $\S$-de 2, 2.1 ja 26 ning kohaliku omavalitsuse volikogu valimise seaduse $\S$-de 3, 3.1 ja 26 muutmise seadus. Riigi Teataja I, 2001, 95, 588.

Riigikogu 2016= Riigikogu võttis ühistranspordiseadusest välja taksojuhtide keeletaseme nõude. <http://www.riigikogu.ee/istungi-ulevaated/riigikogu-vottis-uhistranspordiseadusest-valja-taksojuhtide-keeletaseme-noude/>. Vaadatud 18.10.2016.

Tomusk, Ilmar (2002) "Riigikeel on riigi keel”. Õiguskeel 1, 10-15.

Tomusk, Ilmar (2002) "Riigikeele oskuse nõudest rahvaesindajaile ja selle kaotamisest". Akadeemia 9, 1832-1859.

Tomusk, Ilmar (2004a) "Vaidlused kohaliku omavalitsuse asjaajamiskeele üle Narvas ja Sillamäel”. Õiguskeel 4, 19-27.

Tomusk, Ilmar (2004b) "Keelejärelevalvest vene õppekeelega koolis - tulemusi ja järeldusi”. Haridus 11, 24-26.

Tomusk, Ilmar (2006) "Kohaliku omavalitsuse tippametnike eesti keele oskusest." Õiguskeel 3, 3-8.

Tomusk, Ilmar (2016) “Arstide keeleoskusest keelejärelevalve pilgu läbi”. Õiguskeel $3,1-10$. 


\begin{abstract}
Ilmar Tomusk: The constitution of the Republic of Estonia on the basic principles of language use, and their application. The article examines the rules of language use provided by the Constitution of the Republic of Estonia. The aim of the article is to find out to what extent the rules of language use ensure the use of the Estonian language in all key areas of life, whether they are sufficient for the development and protection of the Estonian language, and whether they guarantee the linguistic rights of individuals.

The analysis of the language provisions of the Constitution shows that the key principles of language use are worded with sufficient clarity that they meet the objective set in the preamble of the Constitution to guarantee the preservation of the Estonian people, the Estonian language and the Estonian culture through the ages. The use of the Estonian language is guaranteed in constitutional institutions and also in most areas of life.

In some areas (e.g. the administration of local governments, education and health care), however, the implementation of the main constitutional principles of language use on the legislative level is insufficient.

Deficiencies in legislation have been compensated for by state language supervision. But the volatility of language policy, deficiencies in language policy planning and the ignoring of language proficiency problems cannot be compensated for by state language supervision. Language legislation should be aligned with the main constitutional principles of language use.
\end{abstract}

Keywords: Constitution, official language, language of public administration, local government, education, health care, state language supervision 